This is a pre-print version of an article that has been published in the International Journal of Cultural Policy. The published version can be downloaded from:

http://www.tandfonline.com/doi/full/10.1080/10286632.2014.908861

Please cite this article as:

Van der Hoeven, A. (2015). Remembering the 1960s: popular music and memory in Europe. International Journal of Cultural Policy, 21(3), 258-272.

\title{
Remembering the 1960s: popular music and memory in Europe
}

Arno van der Hoeven, department of Media and Communication, Erasmus University Rotterdam.

\begin{abstract}
Following the increasing attention paid to popular music in heritage discourses, this article explores how the popular music culture from the 1960s is remembered in Europe. I discuss the role of heritage organizations, media and the cultural policy of the EU in the construction of a popular music heritage of this period. Furthermore, I examine the ways in which attachments to local, national and European identities are negotiated. To this end, I draw upon interviews with representatives of museums, websites and archives. The article reveals a recurring tension between transnational and local experiences of the sixties. It is found that media and heritage institutions like museums and archives predominantly have a national and local orientation, although narratives with a European vantage point are now emerging on the internet.
\end{abstract}

Key words: popular music; cultural policy; cultural memory; Europe

\section{Introduction}

This article considers how popular music from the 1960s is remembered in Europe. In particular, it will examine the different ways in which it is positioned as the cultural heritage of the baby boomer generation (Bennett 2009) and explore how memories of the sixties 
connect to local, national and European identities. Traditionally, European identity and cultural heritage are seen in connection to high culture (Cohen 2013, Lähdesmäki, 2012). More recently, however, various studies (Bennett 2009, Reitsamer 2014, Brandellero and Janssen 2014) have demonstrated that due to the blurring of the boundaries between 'high' and 'low' culture and the attention paid to social history, heritage discourses increasingly include popular music as an expression of shared identity. Nevertheless, there has thus far been little discussion of the European dimensions of popular music heritage (Cohen 2013 being a notable exception). This is surprising because, as Green and Marc $(2013$, p. 4) argue, Europe is 'a shared contemporary geopolitical reality within which coexist diverse languages and cultural and musical histories linked by organizational structures, common economic policies and cultural affinities that in many ways facilitate more dynamic musical exchange than with other spaces'.

Cohen (2013) argues that the attention paid by the cultural and heritage industries to music of the past can be explained in terms of pan-European trends in cultural policy such as the marketing of cultural memories and the preservation and promotion of local distinctiveness and cultural diversity. The European Union regards the creative and cultural industries as an important economic sector, and uses its cultural policy to foster a sense of belonging in an imagined European community (Sassatelli 2002, Tsaliki 2007, Lähdesmäki 2012). These policy initiatives aim to support, for example, intercultural dialogue, co-operation between cultural organizations and the promotion of a European cultural heritage. This article explores how the popular music memories of the 1960s relate to these pan-European policy initiatives.

The late 1950s and the 1960s saw the advent of a transnational youth culture (Schildt and Siegfried 2006). According to Marwick (2006, p. 44), 'the central component was pop/rock music, which became a kind of universal language, its performers being young in comparison with the crooners and band leaders of the 1950s, and the audiences mainly (though far from exclusively) being very young'. In this period, the music and alternative lifestyles of young people spread across Europe and, despite the differences between Eastern and Western European countries, connected their respective youths (Siegfried 2008). However, national governments on both sides of the iron curtain tried to control what people heard on the radio, fearing that popular music would have adverse effects (Ryback 1990, Chapman 1992). The 
lack of attention paid to new music genres on the state regulated public radio stations provided the impetus for the European phenomenon of offshore radio (i.e. pirate radio). Furthermore, rock music was a significant aspect of the counter-cultural activities that culminated in the protests of 1968. As Siegfried (2008, p.65) argues, 'because certain aspects of rock music, such as spontaneity, physicality, activism, violating the rules, and questioning authority, corresponded with the formal aspects and content of the protest movements, pop and politics became closely intertwined in the everyday lives of many participants'.

This article explores how these developments are remembered in Europe, focusing on the tension between the various geographical levels (i.e. local, national and European) upon which popular music memories are constructed and disseminated. These memories of the popular music from the 1960s not only encompass the music itself, but also, for example, the reception of popular music via pirate radio and youth-oriented music magazines. To be clear, this article does not provide a historical overview of popular music in the sixties, but instead focuses on how the memories of this period are constructed and represented by the cultural and heritage industries. Due to its broad appeal, this decade offers 'rich opportunities to see, in real time, the operation of historical memory and of memory politics - how a past is evoked, constructed, appropriated and contested' (Varon et al. 2008, p. 2). By studying the actors and institutions involved in such memory practices, I examine how the music and memories of this period are given cultural and political value (Street 2013). Although there is much research on the global flows of music, the international aspects of policies on popular music and popular music heritage receive less attention (Homan et al. 2013).

In the next section, I introduce theories on popular music, memory and heritage. Subsequently, I will use this literature to analyze the way in which popular music from the 1960s is remembered in Europe, focusing on the relationship between local memories of this period and the pan-European aims of the European Union's cultural policy.

\section{Theorizing music, memory and heritage}

Music and memories are able to constitute imagined communities (Anderson 1991, Kong 1997, Turino 1999). As Eder (2005, p. 205) argues about the meaning of collective memory: 
'Remembering the past means creating a particular social relationship with those who equally share a significant reference to that past.' This sense of community could, for example, be present when a large number of listeners from a specific country tune in to the same radio show (Van Dijck 2006). Neiger et al. (2011) demonstrate how popular music is used as a 'mnemonic cultural object' on Israel's Memorial Day for the Holocaust and the Heroism. The songs broadcast on local radio stations during this public mourning ritual commemorate a shared past and give shape to the national culture of Israel. This example illustrates the pertinence of memory practices to cultural identity construction. Furthermore, as a ubiquitous cultural form, music is able to evoke the general mood of a particular era (Van Dijck 2006), personal experiences, historical events and a sense of nostalgia. In relation to this, Turino (1999) describes how musical signs operate as a form of 'semantic snowballing'. Music refers to many aspects of social life, has multiple meanings, and the memories and associations attached to it are ever expanding. The cultural and heritage industries further cement the connections between music and memory through their presentation of popular music as a form of cultural heritage.

Following on from the increasing cultural legitimacy of popular music, which is manifest by its inclusion in cultural policies (Looseley 2011, Nuchelmans 2002, Van der Hoeven 2012) and the coverage given to the arts and culture in elite newspapers (Janssen et al. 2011, Schmutz et al. 2010), popular music has become part of heritage discourses (Brandellero and Janssen 2014). Bennett observes how the rock aesthetic that emerged in the 1960s is strongly connected to the identity of the baby-boomer generation:

The heritage rock discourse is very much part of the ageing rock audience's reassessment of rock, not merely as something particular to their youth, but rather as a key element in their collective cultural awareness and a major contributor to their generational identity. (2009, p. 478)

However, younger generations are also attracted to the musical heritage of the 1960s (Bennett 2008, Hayes 2006). Furthermore, narratives of popular music heritage are not only connected to generational identities, but are also linked to notions of place. For example, museums 
(Burgoyne 2003), documentaries (Reitsamer 2014) and tourist organizations (Brandellero and Janssen 2014) give shape to popular music as a form of local and national heritage.

Such heritage practices invoke memories as building blocks of cultural identities. Therefore, heritage not only concerns the past, but also serves needs in the present (Smith 2006). This implies that narratives of the past are not fixed; their form depends on the ways in which memories are given meaning in the present. These political claims on the past are manifest in the European project (Lähdesmäki 2012).

The European Union mobilizes cultural heritage in order to construct a European identity that is grounded in a shared past (Bee 2008). However, this idea of a common European heritage has been criticized because it essentializes European identity into a homogenous narrative, ignoring the diversity of European cultures (Sassatelli 2002, Lähdesmäki 2012). Delanty (2000, p. 235) argues that social integration and cultural cohesion is impossible if we take the plurality of the different member states into consideration: 'The idea of cultural cohesion presupposes too much homogeneity, such as that associated with national identity and which is unrealistic as well undesirable as a model of Europeanization.' This tension between unity and diversity has been resolved in the communications of the European Union with the motto 'United in diversity' (Bee 2008, Lähdesmäki 2012). ${ }^{1}$ In relation to this, article 128 of the Maastricht Treaty (European Commission 1992) states that 'the community shall contribute to the flowering of the cultures of the Member States, while respecting their national and regional diversity and at the same time bringing the common cultural heritage to the fore'.

These complexities of a European identity are apparent in the Eurovision Song Contest, which has been organized by the European Broadcasting Union since 1956. According to Sandvoss (2008), this contest 'forms visions of Europe for those on the inside as much as on the outside of the continent'. These visions encompass contested notions of the relationship between national and European identities: 'Paradoxically, while Eurovision seeks to invoke the imagery of a transcendental European culture, it actually reinforces national caricatures. The contest's amorphous internationalism draws attention to the reality of European cultural fragmentation, rivalry, and economic ambition' (Coleman 2008, p. 131). 
Although various authors have explored the tensions between national and European identities in the European Union's cultural policies (Dittmer 2014, Gordon 2010, Lähdesmäki, 2012, Tsaliki, 2007), less is known about the role of popular music's past in these debates. Most research on popular music heritage has focused on the connections between popular music memory and national identity. However, referring to music's transnational reach and ability to call forth personal and collective memories, Cohen (2013, p. 590) concludes that 'popular music contributes to cultural memory in distinctive and multifaceted ways, and therefore has a specific significance for cultural policy and the new Europe'.

The popular music of the 1960s is a relevant starting point for such an inquiry because of the international character of the developments in this decade. As the editors of 'The Sixties' argue in the first issue of this journal (Varon et al. 2008, p. 5), in times of globalization it is important to understand 'the means of connection, mutual influence, and tension between nations, geographies, and cultures'. Although popular music is a very mobile cultural form, which easily crosses boundaries of all types (Frith 1996), language barriers and cultural differences complicate the transnational exchange of musical experiences (Marc 2013). These considerations lead to the following research question: how do narratives of the popular music heritage of the sixties - as they are constructed and disseminated by the cultural and heritage industries - resonate with cultural identities on local, national and European levels?

\section{Background to the study}

Wertsch (2000) argues that memories rely on cultural tools that mediate active processes of remembering. For example, documentaries and museum exhibitions provide narratives with which audiences can identify. As Brandellero and Janssen (2014, p. 224) found, 'heritage is both a source of identity and a receptor of value attributed to it by communities, institutions and people'. I will therefore explore how the practices of the cultural and heritage industries resonate with cultural identities and give the music from the 1960s political and cultural value (Street 2013). 
In order to conduct a representative study of the ways in which popular music from the sixties is remembered in Europe, I will discuss the memory practices taking place in established institutions (on EU, national and local levels), as well as heritage and preservation initiatives by non-professionals such as amateur archivists and bloggers. The data upon which this article is based have been collected in the context of the research project 'Popular Music Heritage, Cultural Memory, and Cultural Identity', which aims to assess the role of popular music in the negotiation of cultural identity in a local, national and European context. The research for this project was conducted at Erasmus University Rotterdam, the universities of Liverpool and Ljubljana, and Mediacult, Vienna.Workshops held with local heritage practitioners in each of the countries helped me to familiarize myself with different preservation and heritage practices across Europe. Furthermore, semi-structured interviews were conducted with the editors of the websites Europopmusic.eu and Ready Steady Girls and representatives of Museum Bokrijk (Belgium), Museum RockArt, Limburgs Museum Venlo (both in the Netherlands) and Europeana. The interviews with the editor of Ready Steady Girls and two representatives of Museum Bokrijk were conducted by telephone; all of the others were 'face-to-face'. Furthermore, I attended sixties-related exhibitions in the York Castle museum (United Kingdom), Limburgs Museum Venlo and Museum RockArt. These visits allowed me to see how the music from this period is represented in a museal context.

In the next section, I give a brief introduction to the musical developments in Europe in the 1960s and the sociocultural themes with which the decade is associated in narratives of cultural heritage. This leads to a discussion of the ways in which this heritage is represented by the cultural and heritage industries, focusing on the tensions between identities on local and European levels.

\section{Remembering the 1960s: music and memory in Europe}

Cultural industries use a focus on decades - the sixties in this case - as a way to segment popular music history in discrete and identifiable periods (Kotarba 2002, Van der Hoeven, 2014). Through numerous books, documentaries, exhibitions and magazines, the 1960s have been heavily mythologized (Varon et al. 2008). Indeed, for baby-boomers and younger 
generations alike, this decade is perceived as a golden age of popular music, full of musical experimentation and development. In this period, album-oriented rock musicians started to distinguish themselves from the more commercial chart music (Bennett 2009). According to Bennett (2008, p. 266), the rock heritage discourses position particular rock musicians of the late 1960 s and early 1970 s 'as key contributors to the essential character of late twentiethcentury culture per se and an integral aspect of the way in which this era of history is to be remembered, represented, and celebrated'. As a consequence, these musicians are not only revered because of their role as counter-cultural icons, but also for their musical accomplishments (Bennett 2009).

The main reference points in any narrative of the 1960s are the Beatles and the Rolling Stones. In the sixties, beat groups from Britain dominated the European radio airwaves and record sales. These bands combined American music styles with influences from Europe (Pells 1997). Frith (1989, p. 168) highlights the connections between Britain and continental Europe in the period before British beat groups became popular in the United States:

Before then (something conveniently forgotten now) British cover versions of rock'n'roll were as unconvincing as those of any other European country (so that Johnny Halliday was, for example, rather better than Cliff Richard at being Elvis Presley). And British pop fans were certainly less cool, less hard than their European peers - the Beatles, after all, learned what live rock'n'roll really meant in Hamburg, and the mod look was rooted in a fantasy of Frenchness, in the allure of the 'discotheque'. The stylishness with which British bands played American music might have been a result of their art school education, but their look was clearly continental — by David Bailey from a film by Jean-Luc Godard, by John Stephens from a street in Rome.

In particular, the Beatles paved the way for the plethora of beat groups emerging on the continent. Although British musicians were at the forefront of the cultural revolution of the decade, other countries also cherished their own successful bands. While musicians on continental Europe initially mainly copied their British heroes, they also developed their own styles, for example by singing in their native languages and dialects (Schildt and Siegfried 2006, Cohen 2013). In France, artists like Johnny Halliday mimicked Anglo-American hits 
and gave them French lyrics (Looseley 2005), hence the label yéyé music, which refers to the Anglo-Saxon 'Yeah, yeah!'. In Eastern Europe, bands that were heavily influenced by the Beatles, such as Illés in Hungary, Olympic in Czechoslovakia and Czerwone Gitary in Poland, targeted local audiences (Ryback 1990). In the Eastern bloc countries, this music was part of the continuous struggle with communist leaders who tried to repress rock music. According to Ryback:

In a very real sense, the triumph of rock and roll in Eastern Europe and the Soviet Union has been the realization of a democratic process. Three generations of SovietBloc youths have compelled governments to accept step by step a cultural phenomenon long decried as an outgrowth of Western capitalism. In the course of thirty years, rock bands have stormed every bastion of official resistance and forced both party and government to accept rock-and-roll music as part of life in the MarxistLeninist state. (Ryback, 1990, p. 233)

This shows that music is connected to developments in the arts, fashion, media and the counter-cultural politics that together shaped the identity of the post-war baby-boomer generation (Bennett 2009). According to Klimke and Scharloth (2008, p. 6): 'The synesthaetic nature of rock music served as the colorful display and global transmitter of [...] new symbolic forms of living and communication.' The curator of the 1960s exhibition 'Flower Power' in Limburgs Museum Venlo explains how they deliberately presented music in relation to such sociocultural developments:

We wanted to make an accessible, big exhibition. Flower Power can be approached from different vantage points. You could focus on one theme, the fashion or art of that period, but our starting point was the flower as a symbol of peaceful protest. We found that there are a lot of themes which are all related to each other. Peaceful protests, then you also think of music and youth culture. But youth culture is inseparable from music and clothes; art is closely related to that, and new ideas about sexuality and societal developments as well. This is all related. You could highlight one theme, but we wanted to keep it broad.

This echoes Turino's (1999) observation that music, as a form of semantic snowballing, has multiple layers of meaning. As narratives of the sixties are strongly related to the identity of 
the baby boomer generation, their presentation in, for example, exhibitions, books and documentaries, often features objects such as mopeds, magazines, transistor radios and furniture. These objects are transnational symbols of the increased prosperity and independence of this generation (Marwick 2006). Interestingly, the sixties exhibitions in Bokrijk, Venlo and York all lead visitors through various shops such as fashion boutiques and a record store. This seems to signify the advent of a consumer culture revolving around a shared lifestyle. Young people became more independent and mobile now that they possessed their own mopeds. Furthermore, with transistor radios, they were able to receive the pirate stations that broadcast youth-oriented programs: 'Although these radio stations mostly stayed away from explicit politics, their youth-specific, frequently unconventional, and at times subversive aura helped ensure that contemporary ideals ranging from individualism to rebellion would reach a large number of European youth' (Siegfried 2008, p. 61).

In the remainder of this article, I will examine the institutional settings in which these events are remembered. I discuss consecutively how (EU) cultural policy, heritage organizations and media negotiate the connections between the popular music heritage of the 1960s and cultural identities on local, national and European levels.

\section{The sixties as cultural heritage}

\section{EU cultural policy}

According to the Eurobarometer (European Commission, 2013), close to six in 10 respondents regard themselves as citizens of the European Union. It has been argued that identification with Europe is widespread, but not as strong as the identification with national governments (Delanty 2005, Fligstein et al. 2012). For this reason, the European Union uses its cultural policy to foster a sense of belonging to the European community and to construct a European cultural identity (Lähdesmäki 2012, Sassatelli 2002). This has to ensure that Europe is not reduced to just an economic entity (Tsaliki 2007). The three main objectives of the EU Culture Program between 2007 and 2013 were the promotion of intercultural dialogue, the transnational mobility of people working in the cultural sector and support for the transnational circulation of cultural and artistic works (European Commission 2010). In

line with these objectives, the European Music Office aims for the conception and 
implementation of a coordinated music policy (EMO nd). According to the EMO Secretary General, Jean-François Michel, music is the best form of art to enhance social integration and develop intercultural dialogue: 'The millions of people who travel to foreign festivals, who buy foreign records or simply play foreign music show that music breaks national borders, and eventually that music is making Europe' (EMO nd). Specific music projects used by the EU to support intercultural dialogue are the European Talent Exchange Program and the European Border Breakers Awards. Both projects aim to increase the transnational mobility of musicians and their works. However, these initiatives focus on contemporary artists, meaning that, currently, a European popular music heritage is not explicitly part of the EU's cultural policy. Similarly, Brandellero and Janssen (2014, p. 228) also found that at the national level 'music heritage and popular music heritage in particular remain relatively undefined'. As a quite recent phenomenon, popular music heritage is rarely explicitly mentioned in cultural policies. However, as an outcome of EU cultural policy, the sixties heritage is indirectly remembered and preserved.

Cohen (2013) demonstrates how Liverpool's year as the European Capital of Culture in 2008 was used to raise awareness of popular music heritage in Europe. The aim of the European Capital of Culture award is to highlight both the diversity of European cultures and their relationship to a common European cultural heritage. However, Cohen (p. 578) demonstrates that the various activities in Liverpool presented the music from this city as local heritage in order to brand the city and potentially improve its economy: 'The organisers thus used the event to celebrate Liverpool's rock past and future, particularly the city's connection with the Beatles and the continuation of that legacy through contemporary rock bands such as the Wombats.' This echoes Sassatelli's (2002) analysis of the European Capital of Culture in the year 2000. To mark the new millennium, the title was awarded to nine cities. Sassatelli found that, predominantly, the specificities of the different cities were promoted and less attention was paid to the European dimension of their heritage. In that sense, the European Capital of Culture project is in line with the EU's United in Diversity motto (Lähdesmäki 2012).

Another instance of sixties popular music heritage as the indirect outcome of EU policy is the website Europeana. This project, which is co-funded by the European Union, is an online 
portal that provides access to Europe's digitized cultural and scientific heritage. Europeana aggregates the data that describes the digitized objects in the collections of European heritage organizations and makes it available in a multilingual environment. Purday (2009) explains that Google's plans to digitize the printed word in collaboration with libraries from the UK and US provided the impetus for the Europeana project; it was feared that Google's focus would be on Anglophone content. At the launch of Europeana in 2008, José Manuel Barroso, the president of the European Commission (quoted in Purday, p. 931), explicitly connected the potential outcomes of this project to the meaning of cultural heritage for a sense of European identity: 'I believe that Europeana has the potential to change the way people see European culture. It will make it easier for our citizens to appreciate their own past, but also to become more aware of their common European identity.'

The Europeana database comprises a wide range of sixties-related photos and videos. A representative of Europeana explains the importance of music in its collection:

It's very popular with the users. I think, we don't really, there won't ever be equal representation, but we would just like it to be, you know, for there to be a good crosssection of music that represents European culture or the individual culture of each country. And music is a really important part of that. So we would like that to be represented and equally represented across the European countries. [...]. And music is something that people relate to a lot and it is something that people actively search for. That is, you know, one of the areas where its importance lies.

The majority of these music-related items in the Europeana dataset come from the sub-project Discovering Music Archives (DISMARC). ${ }^{2}$ This aimed to further enhance the visibility of Europe's music heritage and has added the content catalogues of music archives to Europeana's database.

\section{Local and national heritage institutions}

Heritage institutions on national or sub-national levels, such as museums, archives and libraries, give shape to popular music as a form of cultural heritage (Burgoyne 2003). Massproduced cultural forms like music have found their way into museums following the increased legitimacy of popular culture (Bennett 2009, Brandellero and Janssen 2014). 
However, in Europe, there are notable differences in the way popular music is positioned as 20th century cultural heritage (Cohen 2013). As suggested by a study of popular music coverage in elite newspapers (Schmutz et al. 2010), the extent to which popular music gains cultural legitimacy in a given country depends on the size and centrality of the cultural production there and the openness to popular culture in its cultural policies and education Whereas the United Kingdom and the Netherlands have museums dedicated to popular music, Zevnik (2014) found that in Slovenia there is not yet a clear agenda on the preservation of popular music's past. Furthermore, in Austria, the national identity is more associated with classical than popular music. Nevertheless, also in this country, the desires of ageing musicians and producers 'to consecrate the music of their youth as well as their involvement in the cultural industries and the state cultural bureaucracy seem to have a profound impact on the national, regional and local cultural policy, including (rock) heritage policy' (Reitsamer 2014, p. 340).

Generally, national, urban and regional heritage institutions engage with the global and local dimensions of the sixties instead of the decade's European aspects. Museums and archives present popular music's past as local heritage and address how global music genres resounded in particular localities (Van der Hoeven and Brandellero 2012). The native languages in which music is sung, the places where artists are from and the local topics addressed in lyrics resonate with cultural identities connected to specific localities. As a consequence, both music and heritage offer a sense of place (Brandellero and Janssen 2014). Moreover, heritage institutions often have a specific geographical remit, as laid down in the organization's aims. An example of this is the Belgium open-air museum Domein Bokrijk, which opened a permanent sixties village in 2012. The coordinator of this exhibition explains why the focus is on Belgium:

Bokrijk tells the story of everyday life in the past. We talk best about Flanders and Belgium, because that is what we can acquire and find. It would not make sense to all of a sudden present the big American story in Bokrijk. It would be nice, but then we need to look for other material and it would be a change of style from the open-air museum. (Coordinator 'The Sixties', Museum Bokrijk) 
This does not mean that the international aspects of the sixties are absent in local exhibitions such as the one in Bokrijk. However, the focus is generally on the local appropriation of global events. For example, the histories of local youth cultures and protest movements, such as the mods in England and the nozems in the Netherlands, are presented. The Beatles and the Rolling Stones are also a recurring theme in exhibitions (Van der Hoeven and Brandellero 2012) along with local bands that appropriated their style. Furthermore, these exhibitions focus on the local reception of media that were used to discover new music. Each country had different youth magazines, television shows or (pirate) radio stations (Schildt and Siegfried 2006). Even in the case of transnational media, the focus can be on local reception. A 2012 exhibition organized by the Luxembourg Embassy in Warsaw and the Institute of Ethnology and Cultural Anthropology of Warsaw University, for example, looked at the sociocultural role of Radio Luxembourg in Poland during the cold war. ${ }^{3}$ This exemplifies how local museums and archives generally relate to place-bound reference points.

\section{Media}

Media are pivotal in negotiating a sense of belonging in what Anderson (1991) has defined as imagined communities. For example, television, radio and the internet disseminate cultural memories that constitute cultural identities. Such 'mediated memories' enable people to connect their personal experiences to a collective cultural memory (Van Dijck 2006). Thus, in relation to the popular music of the sixties, media provide narratives of popular music's past with which audiences can identify. Reitsamer (2014, p. 340), for example, analyzes two Austrian multi-media projects which demonstrate 'how the global circulating discourse of "rock as heritage" has been translated into the national context with the aim of constructing an Austrian "rock heritage" and inscribing it historically as an integral aspect of the Austria's national cultural heritage'.

On a transnational level, a European communicative space could contribute to the constitution of a shared European collective memory of popular music from the 1960s. In relation to this, Eder (2005, p.213) argues that 'the more people share a communicative space that transgresses the confines of old memories, the more these memories are reorganized on a higher level, so that these memories make sense as a whole'. However, the European public 
sphere remains very small compared to national communicative spaces: 'While European transnational communication space is growing and attracting influential elite audiences, the role of transnational media in reaching out to the broader European public remains very modest' (Brüggemann and Schulz-Forberg 2009, p. 707). Interestingly, this is, to a certain extent, in contrast with the 1960s, when European citizens in various countries listened to the same offshore pirate radio stations to discover new music (Schildt and Siegfried 2006), and young people in Eastern bloc countries tuned in to Western radio stations like Radio Free Europe and Radio Luxembourg (Ryback 1990). However, mediated narratives of the sixties often revolve around particular countries. For example, television documentaries commemorating the sixties are produced by national or sub-national broadcasting organizations, targeting domestic audiences.

Exceptions are the earlier mentioned Europeana, which is a multilingual online access point to Europe's cultural heritage, and the European cultural television channel ARTE. Although ARTE focuses on Germany and France, its 'summer of the sixties' series presented documentaries, concerts and television programs from a transnational vantage point. ${ }^{4}$ However, language barriers and cultural differences remain an obstacle to European media (Brüggemann and Schulz-Forberg 2009, Dittmer 2014). This scarcity of European narratives of popular music history was a reason for two music fans to establish an online magazine and encyclopedia about European popular music: ${ }^{5}$

We found out that if you search for particular artists, like who is it and who is behind it, not much information is available. And, if there is any, it is in that specific language. [...] So you have to translate it. (Editor Europopmusic.eu) Like the website Ready Steady Girls, which focuses on European female singers from the sixties, a personal interest in the Eurovision Song Contest was also an impetus behind the European vantage point. ${ }^{6}$ Ready Steady Girls documents the musical exchanges between European countries, like the French yéyé phenomenon which also reached Spain. Yéyé girls adopted Anglo-American musical songs with lyrics in their own language. An exponent of this style is the French singer France Gall, who, representing Luxembourg with the song Poupée de cire, poupée de son, won the 1965 Eurovision Song Contest. 
These websites are examples of do-it-yourself preservationism (Bennett, 2009), which is a term that describes heritage and preservation activities initiated by fans, enthusiasts and other non-professional actors. According to Bennett (2009, p. 483), 'such instances of DIY preservation are becoming increasingly common, to the extent that they can no longer be regarded merely as isolated incidents of fan innovation, but they constitute a globally connected informal network of activity orientated towards a re-writing of contemporary popular music history'. Similarly, Cohen (2013) argues that such projects could challenge dominant representations of popular music's past. She explains that these 'micro or hidden musical histories' have been enabled by new digital tools for sharing information on the internet (e.g. web 2.0, social media) and are emerging in many European cities. Although most discussions of DIY preservationism focus on its role in narrating and preserving local music histories and identities (Brandellero and Janssen 2014, Cohen 2013, Roberts 2014), such activities also offer opportunities to chart musical exchanges and connections between countries. As a translocal medium, the internet enables fans and music enthusiasts to explore Europe's popular music heritage and present particular music histories that are overlooked by established media. Other examples of such an approach are the websites dedicated to offshore radio in Europe. These sites contain histories, recordings, jingles and photos of these pirate radio stations and make them available online. ${ }^{7}$ As the website Offshore Echo's states:

The offshore stations, set up on board ships and forts, are at the heart of modern radio in Europe. They were extremely popular throughout the 1960s \& 70s and into the 1980 s, when they were the only stations to provide young people with an exclusively music format. The listeners called them 'Free Radio stations' - the authorities 'Pirate Radio'. While famous offshore radio stations like Radio Caroline no longer broadcast freely from international waters, the memories of offshore radio are far from dead. ${ }^{8}$ For these online platforms, language is no obstacle to engaging with Europe's popular music heritage. In contrast to traditional media such as newspapers or television, they are able to present their content in English or even in a multilingual digital space. Although these nonprofessional projects might not have the same legitimacy and standards as established media and heritage organizations (Roberts and Cohen 2014), they do diversify the narratives of the popular music of the sixties. 


\section{Conclusions}

The aims of this article were to examine the ways in which popular music from the sixties is remembered in Europe and how these relate to local, national and European identity construction. Although this paper has discussed many public and private initiatives to preserve and document the popular music heritage of this period, it concludes that cultural policies on the preservation of popular music are underdeveloped to date. Like earlier research has demonstrated for specific countries (Brandellero and Janssen 2014, Zevnik 2014), on a European level there is neither a clear agenda on popular music heritage nor a coordination of activities in this field. Even though the cultural policy of the European Union indirectly leads to the preservation of popular music through projects such as Europeana and the European Capital of Culture, European narratives of the sixties are scarce in comparison with the many local accounts of this period. Books, documentaries and exhibitions on the popular music from the sixties generally focus on specific countries. As a consequence, the memory practices of the cultural and heritage industries resonate more strongly with local and national identities than with a European perspective. This mirrors the variation in musical reference points in different European countries. Although all countries have seen the emergence of a youth culture influenced by cultural styles from the US and UK, each country also has its own local musical heroes and media through which it familiarizes itself with new musical styles. This divergence of experiences of the sixties can be neatly summarized with the European Union's United in Diversity motto.

The fact that there is also often a plurality of musical identities on the national level should temper the expectations of a coherent European narrative. However, as Eder (2009, p. 444) argues in a study of European identity, the plurality of narratives does not preclude a shared European perspective: 'Instead of imposing a hegemonic "grand narrative", Europe can live with a diversity of stories that need only one property: to offer nodes as docking stations for other stories.' To give a musical example of such a 'narrative network' (Eder 2009), the traveling Europunk exhibition examined the visual expressions of punk in its international dimensions. The accompanying catalogue (De Chassey 2011), which is published in three languages, shows how the visual culture of punk music spread across Europe in the 1970s. It contains illustrations of posters, apparel, fanzines and record covers from local music scenes 
and their visual approaches to punk. Like some of the websites and historical works discussed in this article, Europunk explores the connections between European countries. It overcomes a narrow focus on one place by also looking at the sociocultural associations between places. As Green and Marc (2013, p. 4) argue, 'to fail to approach anglophone music, and contemporary popular music in general, as part of a multi-lingual and multi-cultural web is to miss a great deal of the evolving, complex reality of the production and consumption of this branch of human activity'.

As popular music heritage is also taking shape in the digital sphere, online exhibitions could be another way of overcoming physical and lingual barriers. Websites such as Europeana and EUscreen (De Leeuw 2011) experiment with virtual exhibitions that showcase the richness of Europe's digital heritage by focusing on specific pan-European themes. Although this article found that a European perspective is largely absent in traditional media and heritage organizations, various private online initiatives aim to preserve European popular music histories. Collaborations between these DIY preservationists and heritage practitioners could enhance the further understanding of the cultural connections between European countries and their shared musical past. Furthermore, the European Parliament aims to raise more awareness of Europe's history with the House of European History, which is to be established in Brussels. ${ }^{9}$ Future research might show whether this museum is able to 'Europeanize' the local experiences of the popular music from the sixties.

\section{Literature}

Anderson, B., 1991. Imagined Communities. London: Verso

Bee, C., 2008. The 'Institutionally Constructed' European Identity: Citizenship and Public Sphere Narrated by the Commission. Perspectives on European Politics and Society, 9 (4), 431-450.

Bennett, A., 2008. “Things they do look awful cool:” Ageing rock icons and contemporary youth audiences. Leisure/Loisir, 32 (2), 259-278.

Bennett, A., 2009. 'Heritage rock': Rock music, representation and heritage discourse. Poetics, 37 (5-6), 474-489.

Brandellero, A. and Janssen, S., 2014. Popular music as cultural heritage: scoping out the field of practice. International Journal of Heritage Studies. 20 (3), 224-240. 
Brüggemann, M., and Schulz-Forberg, H., 2009. Becoming Pan-European? Transnational Media and the European Public Sphere. International Communication Gazette, 71 (8), $693-712$.

Burgoyne, R., 2003. From contested to consensual memory: the rock and roll hall of fame museum. In: K. Hodgkin and S. Radstone, eds. Contested pasts: the politics of memory. London: Routledge, 208-220.

Chapman, R., 1992. Selling the Sixties: The Pirates and Pop Music Radio. London: Routledge.

Cohen, S., 2013. Musical memory, heritage and local identity: remembering the popular music past in a European capital of culture. International Journal of Cultural Policy, $19(5), 576-594$.

Coleman, S., 2008. Why is the Eurovision Song Contest Ridiculous? Exploring a Spectacle of Embarrassment, Irony and Identity. Popular Communication, 6 (3), 127-140.

De Chassey, E., ed., 2011. Europunk: the visual culture of punk in Europe (1976-1980). Rome: Drago.

Delanty, G., 2000. Social Integration and Europeanization: the Myth of Cultural Cohesion. Yearbook of European Studies, 14 (1), 221-238.

Delanty, G., 2005. What does it mean to be a "European"? Innovation: The European Journal of Social Science Research, 18 (1), 11-22.

De Leeuw, S., 2011. Het archief als netwerk. Tijdschrift voor Mediageschiedenis, 14 (2), 10 28.

Dittmer, J., 2014. Towards new (graphic) narratives of Europe. International Journal of Cultural Policy, 20 (2), 119-138.

Eder, K., 2005. Remembering National Memories Together: The Formation of a Transnational Identity in Europe. In: K. Eder and W. Spohn, eds., Collective Memory and European Identity. Aldershot: Ashgate, 197-220.

Eder, K., 2009. A Theory of Collective Identity Making Sense of the Debate on a 'European 
Identity'. European Journal of Social Theory, 12 (4), 427-447.

European Music Office (EMO), nd. Towards a european music policy [online]. Available from: http://www.emo.org/Publish/document/76/TowardsaEuropeanmusicpolicy.pdf

European Commission, 1992, Treaty on European Union Signed at Maastricht on 7 February, Luxembourg: OOPEC.

European Commission, 2010. Programme Guide Culture 2007 - 2013. Available from: http://ec.europa.eu/culture/calls-for-proposals/culture-programme-guide_en.htm [Accessed 10 December 2012].

European Commission, 2013. Public opinion in the European Union . First results.

Standard Eurobarometer 80. Available from: http://ec.europa.eu/public_opinion/ archives/eb/eb80/eb80_first_en.pdf [Accessed 6 February 2014].

Fligstein, N., Polyakova, A., and Sandholtz, W., 2012. European Integration, Nationalism and European Identity. Journal of Common Market Studies, 50, 106-122.

Frith, S., 1989. Euro pop. Cultural Studies, 3 (2), 166-172.

Frith, S., 1996. 'Music and identity'. In: S. Hall and P. du Gay, eds. Questions of Cultural Identity, eds S. Hall and P. du Gay, London: Sage, 108 - 126.

Gordon, C., 2010. Great expectations - the European Union and cultural policy: fact or fiction? International Journal of Cultural Policy, 16 (2), 101-120.

Green, S., and Marc, I., 2013. European popular musics: A polycentric dialogue. Journal of European Popular Culture, 4 (1), 3-7.

Hayes, D., 2006. “Take Those Old Records off the Shelf”: Youth and Music Consumption in the Postmodern Age. Popular Music and Society, 29 (1), 51-68.

Homan, S., Cloonan, M., and Cattermole, J., 2013. Introduction: popular music and policy, International Journal of Cultural Policy, 19 (3), 275-280

Janssen, S., Verboord, M., and Kuipers, G., 2011. Comparing cultural classification: high and popular arts in European and U.S. elite newspapers, 1955-2005. Kölner Zeitschrift für Soziologie und Sozialpsychologie, 63 (special issue 51), 139-168.

Klimke, M. and Scharloth, J., 2008. 1968 in Europe: A History of Protest and Activism, 
1956-1977. New York, NY: Palgrave Macmillan.

Kong, L., 1997. Popular music in a transnational world: the construction of local identities in Singapore. Asia Pacific Viewpoint, 38 (1), 19-36.

Kotarba, J. A., 2002. Rock “n” Roll Music as a Timepiece. Symbolic Interaction, 25 (3), $397-404$

Lähdesmäki, T., 2012. Rhetoric of unity and cultural diversity in the making of European cultural identity. International Journal of Cultural Policy, 18 (1), 59-75.

Looseley, D., 2005. Fabricating Johnny French popular music and national culture. French Cultural Studies, 16 (2), 191-203.

Looseley, D., 2011. Notions of popular culture in cultural policy: a comparative history of France and Britain. International Journal of Cultural Policy, 17 (4), 365-379,

Marc, I., 2013. How do we listen to popular music in Europe? Journal of European Popular Culture, 4 (1), p29-35.

Marwick, A., 2006. Youth Culture and the Cultural Revolution of the Long Sixties. In: A. Schildt and D. Siegfried, Between Marx and Coca-Cola: Youth Cultures Changing European Society, 1960-1980. New York, NY: Berghahn Books, 39-58.

Neiger, M., Meyers, O., and Zandberg, E., 2011. Tuned to the nation's mood: Popular music as a mnemonic cultural object. Media, Culture \& Society, 33 (7), 971 -987.

Nuchelmans, A., 2002. 'Dit gebonk dient tot het laatste toe te worden bestreden' Popmuziek en overheidsbeleid 1975-2001. Amsterdam: Boekmanstudies.

Pells, R., 1997. Not like us: How Europeans have loved, hated, and transformed American culture since World War II. New York, NY: BasicBooks.

Purday, J., 2009. Think culture: Europeana.eu from concept to construction. The Electronic Library, 27 (6), 919-937.

Reitsamer, R., 2014. 'Born in the Republic of Austria' the invention of rock heritage in Austria. International Journal of Heritage Studies, 20 (3), 331-342. 
Roberts, L., 2014. Talkin bout my generation: popular music and the culture of heritage. International Journal of Heritage Studies, 20 (3), 262-280.

Roberts, L. and Cohen, S., 2014. Unauthorising popular music heritage: outline of a critical framework. International Journal of Heritage Studies, 20 (3), 241-261.

Ryback, T. W., 1990. Rock around the bloc: a history of rock music in Eastern Europe and the Soviet Union. New York, NY: Oxford University Press.

Sandvoss, C., 2008. On the Couch with Europe: The Eurovision Song Contest, the European Broadcast Union and Belonging on the Old Continent. Popular Communication, 6 (3), $190-207$.

Sassatelli, M., 2002. Imagined Europe The Shaping of a European Cultural Identity Through EU Cultural Policy. European Journal of Social Theory, 5 (4), 435-451.

Schildt, A., and Siegfried, D., 2006. Between Marx and Coca-Cola: Youth Cultures Changing European Society, 1960-1980. New York, NY: Berghahn Books.

Siegfried, D., 2008. Music and Protest in 1960s Europe. In: M. Klimke and J. Scharloth, eds. 1968 in Europe: A History of Protest and Activism, 1956-1977. New York, NY: Palgrave Macmillan, 57-70.

Smith, L., 2006. The Uses of Heritage. London: Routledge.

Schmutz, V., et al., 2010. Change and Continuity in Newspaper Coverage of Popular Music since 1955: Evidence from the United States, France, Germany, and the Netherlands. Popular Music and Society, 33 (4), 501-515.

Street, J., 2013. Music, markets and manifestos. International Journal of Cultural Policy, $19(3), 281-297$.

Tsaliki, L., 2007. The Construction of European Identity and Citizenship Through Cultural Policy. European Studies: A Journal of European Culture, History and Politics, $24(1), 157-182$.

Turino, T., 1999. Signs of Imagination, Identity, and Experience: A Peircian Semiotic Theory for Music. Ethnomusicology, 43 (2), 221-255.

Van der Hoeven, A., 2014. Remembering the popular music of the 1990s: dance music and 
the cultural meanings of decade-based nostalgia. International Journal of Heritage Studies, 20 (3), 316-330.

Van der Hoeven, A. and Brandellero, A., 2012. The localized popular music heritage of the Netherlands in museums and archives. Paper presented at the international Conference of the European Sociological Association Research Network "Sociology of Culture", 5-7 September. Technical University of Berlin, Germany.

Van der Hoeven, Q., 2012. Van Anciaux tot Zijlstra. Cultuurbeleid en cultuurparticipatie in Nederland en Vlaanderen. Den Haag: Sociaal en Cultureel Planbureau.

Van Dijck, J., 2006. Record and Hold: Popular Music between Personal and Collective Memory. Critical Studies in Media Communication, 23 (5), 357.

doi:10.1080/07393180601046121

Varon, J., Foley, M. S., and McMillian, J., 2008. Time is an ocean: the past and future of the Sixties. The Sixties, 1 (1), 1-7.

Wertsch, J. V., 2000. Narratives as Cultural Tools in Sociocultural Analysis: Official History in Soviet and Post-Soviet Russia. Ethos, 28 (4), 511-533.

Zevnik, L., 2014. Mapping popular music heritage in Slovenia. International Journal of Heritage Studies, 20 (3), 281-296.

\section{Endnotes}

1. http://europa.eu/abc/symbols/motto/index_en.htm (accessed February 2013).

2. http://www.dismarc.org/info/ (accessed March 2013).

3. 'Remembering Radio Luxembourg in the People's Republic of Poland': http:// varsovie.mae.lu/en/Remembering-Radio-Luxembourg-in-the-People-s-Republic-of-PolandWspominajac-Radio-Luksemburg-w-PRL (accessed May 2013).

4. http://www.arte.tv/de/tv-programm/3204632.html (accessed February 2013).

5. http://europopmusic.eu/ (accessed March 2013). 
6. http://www.readysteadygirls.eu/ (accessed March 2013).

7. See http://www.offshoreradio.org, http://www.azanorak.com/ and http://soundscapes.info/ (accessed March 2013).

8. www.offshoreechos.com/About us.htm (accessed March 2013).

9. http://www.europarl.europa.eu/visiting/en/visits/historyhouse.html (accessed February 2013). 